\title{
WPLYW RODZAJU ZASILANIA I KLASY OLEJU NA NOŚNOŚĆ FILMU OLEJOWEGO
}

\begin{abstract}
W artykule przedstawiono wpływ rodzaju zasilania i klasy oleju na nośność filmu olejowego. Pokazano równania rozkładu ciśnienia i temperatury oleju w szczelinach smarowych oraz równanie wysokości szczeliny smarowej. Są one uzupełniane równaniem modelu matematycznego oleju smarującego łożysko. Stwierdzono istotny wpływ lepkości $\eta=\eta(\mathrm{T})$ na nośność filmu olejowego. Wpływ ten rośnie wraz ze wzrostem wartości mimośrodowości względnej $\varepsilon$, niewielki wpływ sposobu zasilania łożyska dla mimośrodowości $\varepsilon \leq 0,55$.
\end{abstract}

Słowa kluczowe: smarowanie hydrodynamiczne, łożyska ślizgowe, szczelina smarowa, film olejowy, mimośrodowość względna, model adiabatyczny

\section{Nomenklatura}

$B$ - szerokość panewki

$C_{R}=0,5 \cdot\left(D-D_{J}\right)-$ luz promieniowy $[\mathrm{m}]$

$D=2 R-$ średnica $[\mathrm{m}]$

$h$ - wysokość filmu olejowego [m]

$F$ - obciążenie

$N, h_{\min }-$ minimalna wysokość szczeliny smarowej [m]

$n_{J}$ - prędkość obrotowa czopa [obr./min]

$p$ - ciśnienie w filmie olejowym $\left[\mathrm{N} / \mathrm{m}^{2}\right]$

$T$ - temperatura $\left[{ }^{\circ} \mathrm{C}\right]$

$x=\varphi \cdot R-$ współrzędna kartezjańskiego układu odniesienia [m]

$y$ - współrzędna kartezjańskiego układu odniesienia [m]

$z$ - współrzędna kartezjańskiego układu odniesienia [m]

$\beta$ - kąt położenia linii środków czopa $\left(O_{J}\right)$ i panewki $(O)$

$\omega_{J}$ - prędkość kątowa czopa [rad/s]

\footnotetext{
1 Autor do korespondencji: Aleksander Mazurkow, Politechnika Rzeszowska im. Ignacego Łukasiewicza, al. Powstańców Warszawy 12, 35-959 Rzeszów, e-mail: almaz@prz.edu.pl, ORCID: 0000-0003-1719-991X.

2 Waldemar Witkowski, Politechnika Rzeszowska im. Ignacego Łukasiewicza, al. Powstańców Warszawy 12, 35-959 Rzeszów.
} 


\section{Indeksy}

$B$ - panewka stała

$J$ - czop

\section{Wprowadzenie}

Poprzeczne łożyska ślizgowe mogą być zasilane świeżym olejem z kieszeni smarowej (rys. 1a) znajdującej się w części nieroboczej filmu olejowego lub też od strony czołowej łożyska (rys. 1b). Podstawę do budowy modeli matematycznych tego rodzaju łożysk stanowią równania rozkładu ciśnienia i temperatury oleju w szczelinach smarowych oraz równanie wysokości szczeliny smarowej. Wspomniane równania są uzupełniane równaniem modelu matematycznego oleju smarującego łożysko [1-5].

Równania rozkładu ciśnienia i temperatury są równaniami różniczkowymi, które rozwiązuje się dla warunków brzegowych odzwierciedlających rzeczywiste warunki pracy łożyska $[6,7]$. W publikacji przedstawiono badania wpływu rodzaju zasilania oraz lepkości oleju na nośność filmu olejowego.

\section{Równania modelu matematycznego łożyska zasilanego z kieszeni smarowej}

Konstrukcję, geometrię oraz przepływ oleju w łożysku zasilanym z kieszeni smarowej ukazano na rys. 1a. Do obliczeń zastosowano metodę przedstawioną w normie [8]. Konstrukcję, geometrię oraz przepływ oleju w łożysku od strony czołowej łożyska przedstawiono na rys. 1b. Model obliczeniowy został zweryfikowany poprzez badania eksperymentalne [8-10].

Model matematyczny stanowi układ równań opisujących:

- rozkład ciśnienia w szczelinie smarowej:

$$
\frac{4}{D^{2}} \frac{\partial}{\partial \varphi}\left(h^{3} \cdot \frac{\partial p}{\partial \varphi}\right)+\frac{\partial}{\partial z}\left(h^{3} \cdot \frac{\partial p}{\partial z}\right)=6 \cdot \eta \cdot \omega_{J} \cdot \frac{\partial h}{\partial \varphi}
$$

Równanie (1) uzyskano po przekształceniach równania zachowania pędu cząstek oleju oraz ciągłości przepływu [8].

- kształt szczeliny smarowej dla geometrii (rys. 1.):

$$
h=0,5 \cdot D \cdot \psi_{R} \cdot[1 \pm \varepsilon \cdot \cos ( \pm \varphi \mp \beta)] \text {, gdzie } \psi_{R}=\frac{C_{R}}{D}
$$

Równanie (2) uzyskano [8], przyjmując układ odniesienia jak na rys. 1a lub rys. $1 b$. 
- rozkład temperatury w szczelinie smarowej w przypadku, gdy ciepło z łożyska jest odprowadzane przez przepływający olej:

$$
\rho \cdot c_{p} \cdot\left[v_{x}^{*} \cdot \frac{\partial T}{\partial x}+v_{z}^{*} \cdot \frac{\partial T}{\partial z}\right]=\eta \cdot\left[v_{x}^{* *}+v_{z}^{* *}\right]
$$

gdzie:

$$
v_{x}^{*}=\int_{0}^{h} v_{x} d y, v_{z}^{*}=\int_{0}^{h} v_{x} d y, v_{x}^{* *}=\int_{0}^{h}\left(\frac{\partial v_{x}}{\partial y}\right)^{2} d y, v_{z}^{* *}=\int_{0}^{h}\left(\frac{\partial v_{z}}{\partial y}\right)^{2} d y .
$$

a)

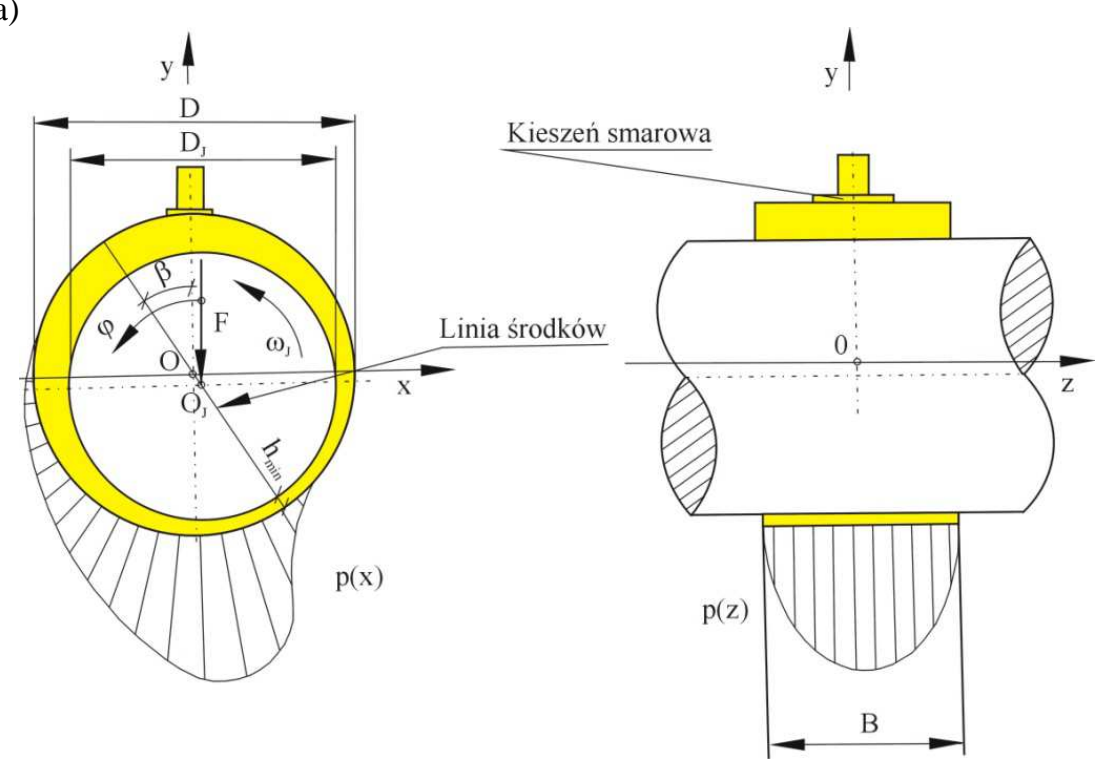

b)
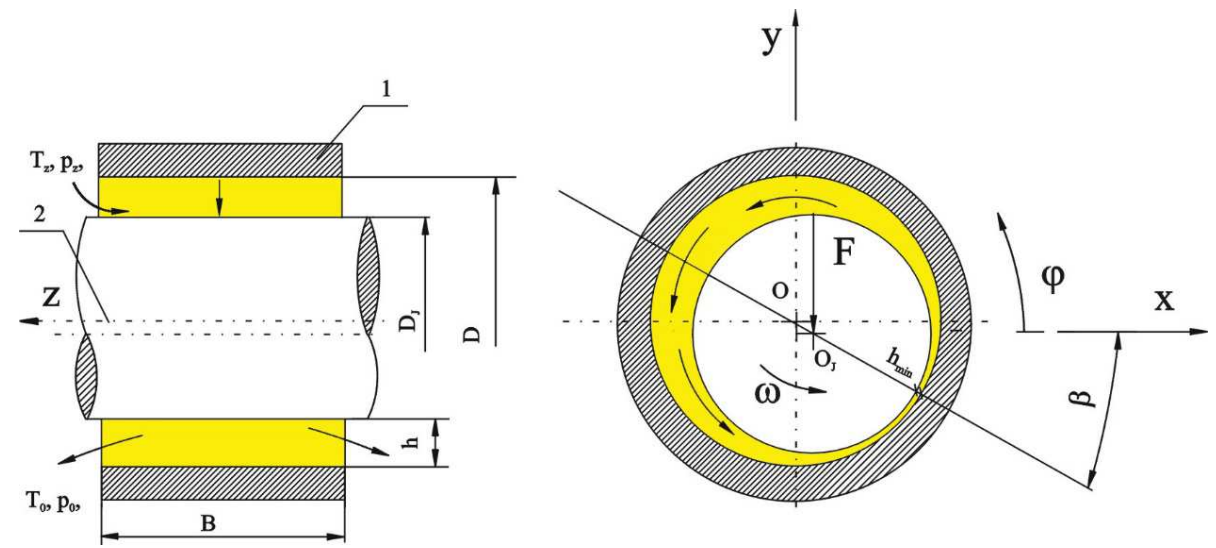

Rys. 1. Geometria i rozkład ciśnienia w poprzecznym łożysku ślizgowym zasilanym świeżym olejem z kieszeni smarowej 
Równanie opisujące rozkład temperatury wyprowadzono z równania bilansu energii [8].

- właściwości oleju smarującego łożysko:

$$
\eta(T)=\eta_{0} \cdot e^{a_{\eta} \cdot\left(T-T_{0}\right)+b_{\eta} \cdot\left(T-T_{0}\right)^{2}}, \rho(T)=\text { const } \quad c_{p}(T)=\text { const }
$$

Do rozważań przyjęto, że olej jest płynem newtonowskim.

W przypadku zasilania łożyska z kieszeni smarowej wzajemnie sprzężony układ równań (1-4) rozwiązano dla warunków brzegowych opisujących pole ciśnienia i temperatury (rys. 2.).

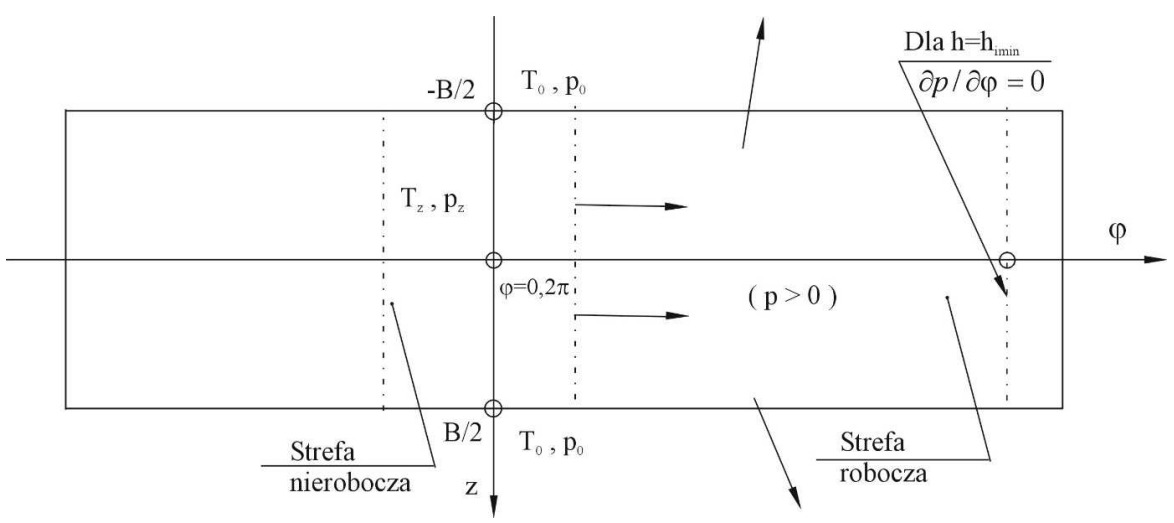

Rys. 2. Warunki brzegowe pola ciśnienia i temperatury dla modelu łożyska zasilanego $\mathrm{z}$ kieszeni smarowej

Dla łożyska zasilanego od strony czołowej łożyska układ równań (1-4) rozwiązano dla warunków brzegowych opisujących pola ciśnienia, które przedstawiono na rys. 3.

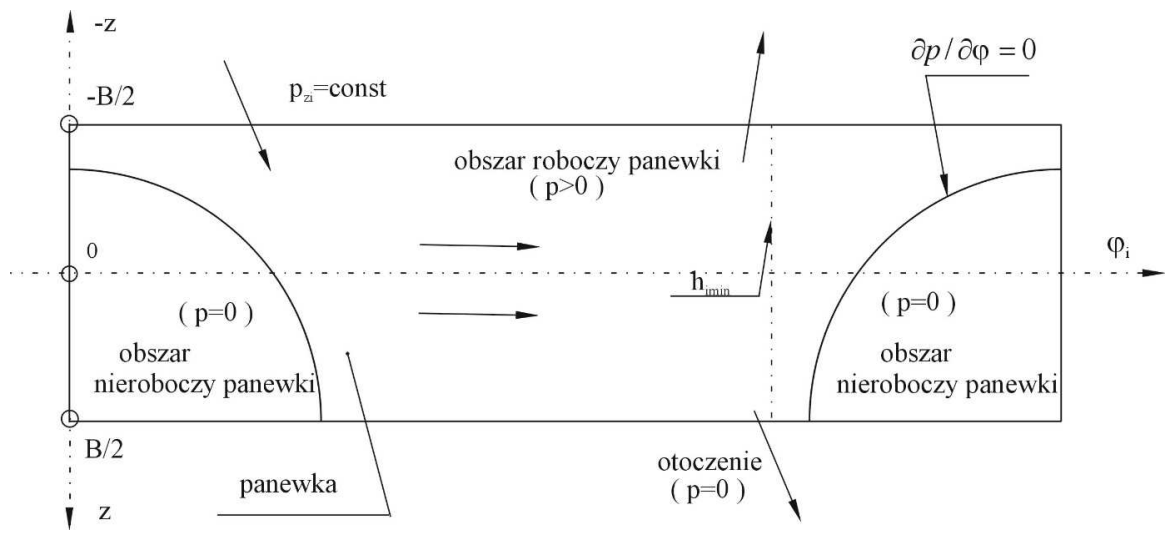

Rys. 3. Warunki brzegowe pola ciśnienia dla łożyska zasilanego od strony czołowej łożyska. Liniami zakończonymi strzałkami zaznaczono kierunki przepływu oleju w łożysku 
Natomiast warunki brzegowe pola temperatury przedstawiono na rys. 4 .

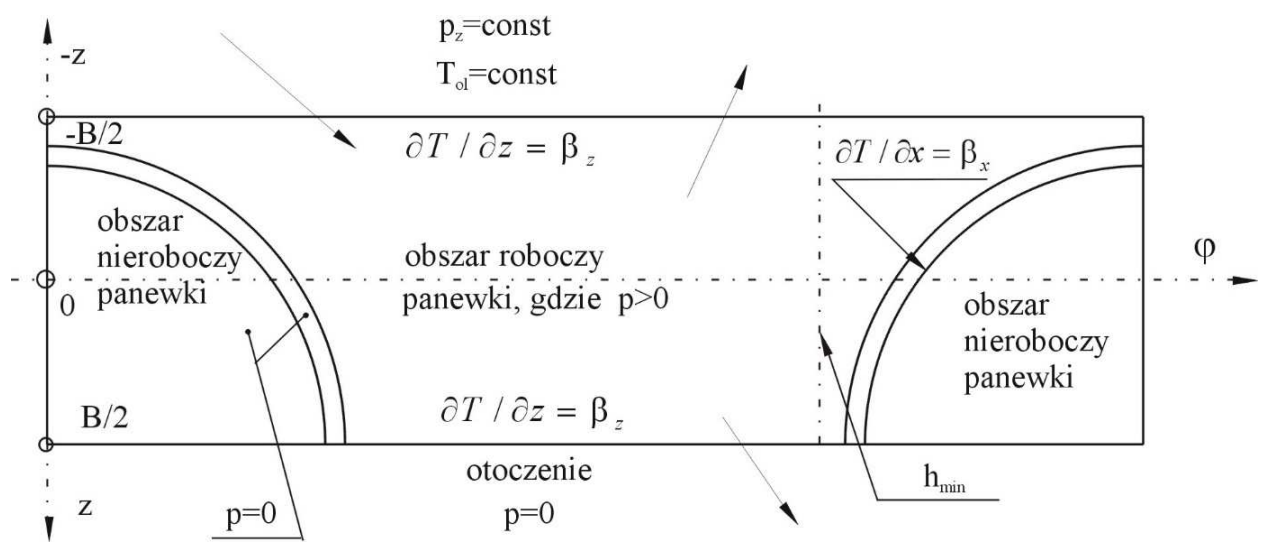

gdzie:

$$
\beta_{x}=\frac{\eta\left(v_{x i}^{* *}+v_{z}^{* *}\right) \cdot v_{x i}^{*}}{\rho \cdot c_{p}\left(\left(v_{z}^{*}\right)^{2}+\left(v_{x i}^{*}\right)^{2}\right)} \quad \beta_{z}=\frac{\eta\left(v_{x i}^{* *}+v_{z}^{* * *}\right) \cdot v_{z}^{*}}{\rho \cdot c_{p}\left(\left(v_{z}^{*}\right)^{2}+\left(v_{x i}^{*}\right)^{2}\right)}
$$

Rys. 4. Warunki brzegowe pola temperatury dla modelu łożyska zasilanego od strony czołowej łożyska

Wynikiem rozwiązania równań równowagi termo-hydrodynamicznej czopa względem panewki stałej są wielkości: $p(\varphi, z), T(\varphi, z), h(\varphi), F=F_{L}$.

\section{Badania porównawcze parametrów pracy łożysk zasilanych z kieszeni smarowych i od strony czołowej łożyska}

Do badań przyjęto oleje o właściwościach przedstawionych w tab. 1. Obliczenia przeprowadzono dla modeli łożyska zasilanego z kieszeni smarowej, jak i od strony czołowej łożyska. Wyniki badań w postaci funkcji $F=F_{L}=f\left(\eta_{0}, \varepsilon\right.$, rodzaj zasilania) zaprezentowano w formie graficznej na rys. 5. oraz w tab. 2 .

Tabela 1. Wielkości zadane

\begin{tabular}{|ll|}
\hline \multicolumn{2}{|c|}{ Parametry zadane } \\
\hline 1. Średnica nominalna czopa & $D_{J}=131,925[\mathrm{~mm}]$ \\
\hline 2. Średnica nominalna panewki stałej & $D=132,109[\mathrm{~mm}]$ \\
\hline 3. Luz względny czop - panewka pływająca & $\psi=1,39 \quad \% 0$ \\
\hline 4. Szerokość względna & $B / D=0,5$ \\
\hline 5. Mimośrodowość względna & $\mathcal{E}=<0,2-0,85>$ \\
\hline
\end{tabular}


Tabela 1 (cd.). Wielkości zadane

\begin{tabular}{|c|}
\hline Parametry zadane \\
\hline 6. Prędkość obrotowa czopa $\omega_{J}=5001 / \mathrm{s}, \quad n_{1}=4774,65$ [obr. $\left./ \mathrm{min}\right]$ \\
\hline $\begin{aligned} \text { 7. Lepkość oleju } & \eta_{0}^{(1)}=0,1084 \mathrm{~Pa} \cdot \mathrm{s}, \quad a_{\eta}^{(1)}=-55291 \cdot 10^{-6}, \quad b_{\eta}^{(1)}=239 \cdot 10^{-6} \\
& \eta_{0}^{(2)}=0,5264 \mathrm{~Pa} \cdot \mathrm{s}, \quad a_{\eta}^{(2)}=-75000 \cdot 10^{-6}, \quad b_{\eta}^{(2)}=349,01 \cdot 10^{-6}\end{aligned}$ \\
\hline 8. Gęstość oleju $\rho_{0}=900\left[\mathrm{~kg} / \mathrm{m}^{3}\right]$ \\
\hline 9. Ciepło właściwe $c_{p 0}=2000\left[\mathrm{~J} / \mathrm{kg} \cdot{ }^{\circ} \mathrm{C}\right]$ \\
\hline 10. Temperatura oleju zasilającego łożysko \\
\hline 11. Ciśnienie oleju zasilającego łożysko \\
\hline
\end{tabular}

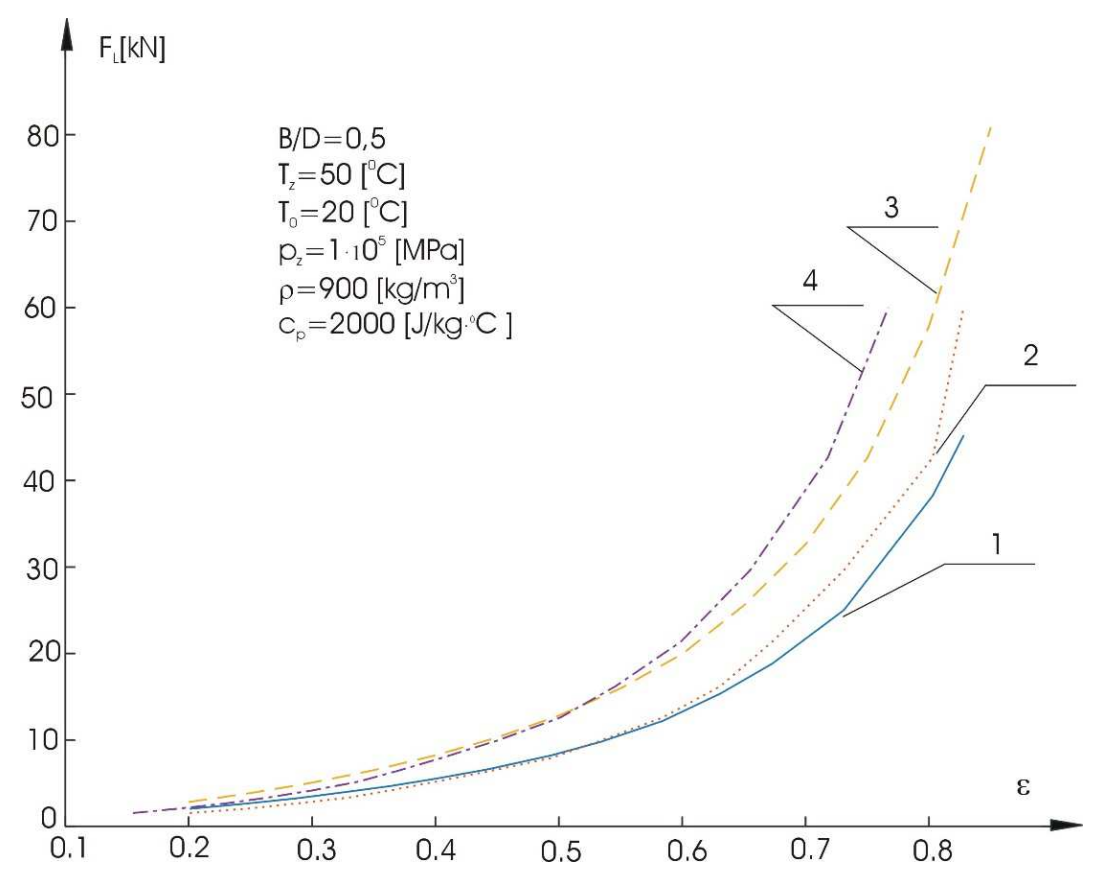

Rys. 5. Wpływ sposobu zasilania i rodzaju oleju na nośność filmu olejowego: $1-\eta_{0}=0,1084[\mathrm{~Pa} \cdot \mathrm{s}]$ zasilanie od strony czoła łożyska, $2-\eta_{0}=0,1084[\mathrm{~Pa} \cdot \mathrm{s}$ ] zasilanie z kieszeni smarowej, $3-\eta_{0}=0,5264[\mathrm{~Pa} \cdot \mathrm{s}$ ] zasilanie od strony czoła łożyska, $2-\eta_{0}=0,5264[\mathrm{~Pa} \cdot \mathrm{s}]$ zasilanie $\mathrm{z}$ kieszeni smarowej 
Tabela 2. Wyniki badań

\begin{tabular}{|c|c|c|}
\hline \multirow{2}{*}{$\begin{array}{c}\text { Lepkość oraz sposób } \\
\text { zasilania }\end{array}$} & \multicolumn{2}{|c|}{ Przyrost nośności filmu olejowego } \\
\hline & $\varepsilon=0,7$ & $\mathcal{E}=0,75$ \\
\hline \multirow{2}{*}{$\begin{array}{l}\text { Zmiana zasilania z czołowego } \\
\text { na kieszeń smarową }\end{array}$} & $\begin{array}{l}\Delta F_{L}=3,7[\mathrm{kN}] \\
\text { dla oleju } \eta_{0}=0,1084[\mathrm{~Pa} \cdot \mathrm{s}]\end{array}$ & $\begin{array}{l}\Delta F_{L}=4,5[\mathrm{kN}] \\
\text { dla oleju } \eta_{0}=0,1084[\mathrm{~Pa} \cdot \mathrm{s}]\end{array}$ \\
\hline & $\begin{array}{l}\Delta F_{L}=6,5[\mathrm{kN}] \\
\text { dla oleju } \eta_{0}=0,5264[\mathrm{~Pa} \cdot \mathrm{s}]\end{array}$ & $\begin{array}{l}\Delta F_{L}=11,0[\mathrm{kN}] \\
\text { dla oleju } \eta_{0}=0,5264[\mathrm{~Pa} \cdot \mathrm{s}]\end{array}$ \\
\hline $\begin{array}{l}\text { Zmiana lepkości } \\
\text { z } \eta_{0}=0,1084[\mathrm{~Pa} \cdot \mathrm{s}] \\
\text { na } \eta_{0}=0,5264[\mathrm{~Pa} \cdot \mathrm{s}]\end{array}$ & $\begin{array}{l}\Delta F_{L}=10,8[\mathrm{kN}] \\
\text { zasilanie od strony czoła } \\
\text { łożyska }\end{array}$ & $\begin{array}{l}\Delta F_{L}=13,5[\mathrm{kN}] \\
\text { zasilanie od strony czoła } \\
\text { łożyska }\end{array}$ \\
\hline $\begin{array}{l}\text { Zmiana lepkości } \\
\text { z } \eta_{0}=0,1084[\mathrm{~Pa} \cdot \mathrm{s}] \\
\text { na } \eta_{0}=0,5264[\mathrm{~Pa} \cdot \mathrm{s}]\end{array}$ & $\begin{array}{l}\Delta F_{L}=13,6[\mathrm{kN}] \\
\text { zasilanie z kieszeni smarowej }\end{array}$ & $\begin{array}{l}\Delta F_{L}=20,0[\mathrm{kN}] \\
\text { zasilanie z kieszeni smarowej }\end{array}$ \\
\hline
\end{tabular}

\section{Omówienie wyników badań}

Analizując przebiegi funkcji $F_{L}=F_{L}\left(\varepsilon, \eta_{0}\right)$ oraz uwzględniając sposób zasilania łożyska świeżym olejem (rys. 5. i tab. 2.), można zauważyć:

- istotny wpływ lepkości $\eta=\eta(T)$ na nośność filmu olejowego $F_{L}$. Wpływ ten rośnie wraz ze wzrostem wartości mimośrodowości względnej $\varepsilon$,

- niewielki wpływ sposobu zasilania łożyska dla mimośrodowości $\varepsilon \leq 0,55$. Wpływ ten rośnie dla wartości mimośrodowości $\varepsilon>0,55$. Łożyska zasilane z kieszeni smarowej mają większą nośność filmu olejowego.

Przedstawione wyniki stanowią pierwszy etap badań. W kolejnym etapie zostanie zbadany wpływ innych parametrów pracy gwarantujących prawidłową pracę łożyska, jak maksymalne ciśnienie i maksymalna temperatura w filmie olejowym.

\section{Literatura}

[1] Barwell F.T., Łożyskowanie, WNT, Warszawa 1984.

[2] Mazurkow A., Właściwości statyczne i dynamiczne, metoda projektowania łożysk ślizgowych z panewką pływającą, Oficyna Wydawnicza Politechniki Rzeszowskiej, Rzeszów 2009.

[3] Mazurkow A., Łożyskowanie ślizgowe, podstawy teoretyczne, właściwości, uszkodzenia, Oficyna Wydawnicza Politechniki Rzeszowskiej, Rzeszów 2013.

[4] Mazurkow A., Wybrane zagadnienia z teorii smarowania łożysk ślizgowych, Oficyna Wydawnicza Politechniki Rzeszowskiej, Rzeszów 2015.

[5] Świderski W., Właściwości adiabatycznego filmu olejowego w poprzecznych łożyskach ślizgowych, Zeszyty Naukowe, nr 706, Politechnika Łódzka, Łódź 1995. 
[6] Kaniewski W., Metodyka konstruowania łożyskowania ślizgowego, Sbornik Praci Wysokié Školy Strojni a textilni v Liberci, 1980, s. 179-180.

[7] Kaniewski W., Warunki brzegowe diatermicznego filmu smarnego, Zeszyty Naukowe Politechniki Łódzkiej 1997, Zeszyt specjalny, z. 14.

[8] Buluschek B., Das Schwimmbüchsenlager bei stationärem Betrieb. Diss. ETH, 1980.

[9] DIN 31652, Teil 1, 2, 3: Hydrodynamische Radial - Gleitlager im stationärem Betrieb.

[10] Mazurkow A., Termodynamiczna teoria smarowania i statyczne charakterystyki ślizgowego łożyska poprzecznego z panewką pływającą, Praca doktorska, Politechnika Rzeszowska, 1993. 